$\mathbb{T}$ periodica polytechnica

Mechanical Engineering

$53 / 1(2009) 27 \sqrt{31}$

doi: 10.3311/pp.me.2009-1.04

web: http://www.pp.bme.hu/me

(C) Periodica Polytechnica 2009

RESEARCH ARTICLE

\section{Requirements of the gas engines considering the use of biogases}

Attila Meggyes / Valéria Nagy

Received 2010-01-18

\begin{abstract}
In the present publication we are examining the requirements of biogases needed by gas engines. Szolnok University College Technical and Agricultural Faculty as well as Budapest University of Technology and Economics are the two main bases of the research. In the course of our research work, of all the potentially available biogases we chose those ones that seem optimal to operate engines - on the grounds of gas production and methane production. The reasons of our choosing are based on the relatively high energy content, the maximum quantity yield, and the as constant output and quality as possible. In the course of the utilization in the internal combustion engine (in biogas engine) we collected some information on what effects the biogases produced by different kinds of recipes have on the operation of the gas engines, the efficiency and performance with special regards to the emission.
\end{abstract}

\section{Keywords}

biogases $\cdot$ gas engines $\cdot$ working range $\cdot$ efficiency $\cdot$ emission

\section{Attila Meggyes}

Department of Energy Engineering, BME, H-1111 Budapest, 3 Múegyetem rkp, Hungary

e-mail: meggyes@energia.bme.hu

\section{Valéria Nagy}

Department of Energy Engineering, BME, H-1111 Budapest, 3 Múegyetem rkp, Hungary

e-mail: valinagy@mfk.hu

\section{Introduction}

The biogases possess different combustion parameters and composition characteristics compared to natural gas [2], so they require different system of conditions compared to heating/burning of natural gas. The application in the gas engines affects the operation of the engine by the emission. Besides the 50-70\% methane content of the chosen biogases, the $\mathrm{CO}_{2}$ content is also significant. The operation of the gas engine can easily be stabilized with greater proportioned concentration of methane (which is combustible gas with great energy content), while the significant $\mathrm{CO}_{2}$ content can be critical from the viewpoint of the ignition of the biogas-air mixture. So the industriallike continuous methane production enables the continuous operation of the gas engine. However, in the case of the utilization of biogases taking place in the gas engine the parameters of gas engines significantly change. The objective of our research work is to analyse what effects different kinds of biogases have on the operation of the gas engines, especially on the moment of the emission. In order to realize this, the two research places examine the energetic utilization of biogases together. The researchers of both research places made gas engine experiments in the György Jendrassik Laboratory of Department of Energy Engineering in Budapest University of Technology and Economics with biogases which were produced for energetic purpose in the laboratory of the Szolnok University College Technical and Agricultural Faculty.

\section{The instrumental system of experimental gas engine}

In the György Jendrassik Laboratory the instrumental system of the experimental gas engine is available the elements of which are:

- $24.6 \mathrm{~kW}$ power, 4 cylinder Wiscon Total TM27 type gas engine,

- 26.4 kW power, 4 pole Marelli CX IM B3 180M type asynchronous generator,

- controller box (starter button, mode switch, locking switch etc.),

- indicating system, 


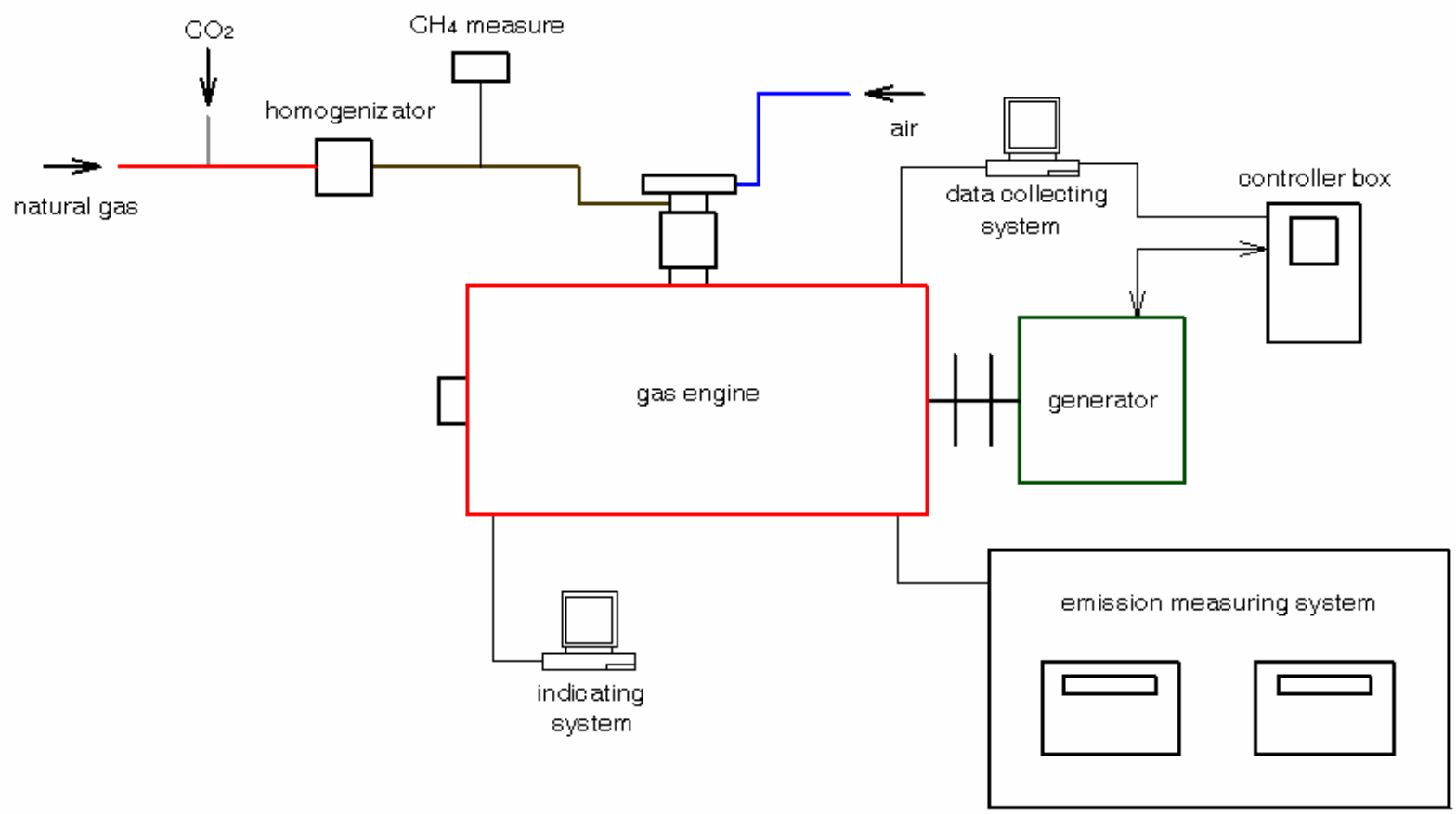

Fig. 1. The experimental gas engine and its complementary parts

- emission measuring system, and

- data collecting system.

The results of the gas engine tests were investigated by Budapest University of Technology and Economics first of all considering the combustion aspects [3], while Szolnok University College Technical and Agricultural Faculty analysed the common results in point of expedience in the gas engines. Our article hereunder presents analysis that is made by Szolnok University College.

Fig. 1 shows the schematic diagram of the experimental set up used with data collecting system, controlling and measuring system.

The experimental gas engine is not a special biogas engine but a conventional natural gas engine, and its gas supply is provided by natural gas pipe. In the interest of the compositions of gases which have lower methane content than natural gas, carbon-dioxide can be mixed to the entering natural gas. Homogenizer provides the steady mixture of the natural gas and the carbon-dioxide, thus different kinds of experimental gas mixtures can be produced. The composition (methane content) of homogenized gas mixtures is determined by gas composition tester (methane tester) which is situated directly joined to the test point behind the homogenizing turbine. The proper mixing rate is provided by the help of de-compressor and throttle valve. Data recording system joined to the gas engines - continuously indicates the effect of the admission air-gas mixture in the gas engines on engine parameters, while the emission is recorded by emission measuring.

\section{Operation of methane-operated engines with biogas}

We have made experiments with gas mixtures which have different kinds of carbon-dioxide content by different kinds of air access coefficients and by added compression ratio, constant boost pressure ( 0.8 bar) and constant speed (1500 1/min). We determined the methane content of the gaseous fuel with gas composition measuring set. In Fig. 2 it can be noticed that by decreasing the methane content of the gases the original working rate of the internal combustion engine narrows, which is confined at one point in case of approximately $52 \%$ methane content. The gas with increasing carbon-dioxide content (biogases) can be utilized with more and more difficulty and at a certain loss in conventional natural gas engines. The taper of working range is shown with broken-line efficiency curves in the figure below. It can be seen in addition that the taper working rate swings to the higher air access coefficients. The engine can operate with leaner mixtures with natural gas as compared to biogas.

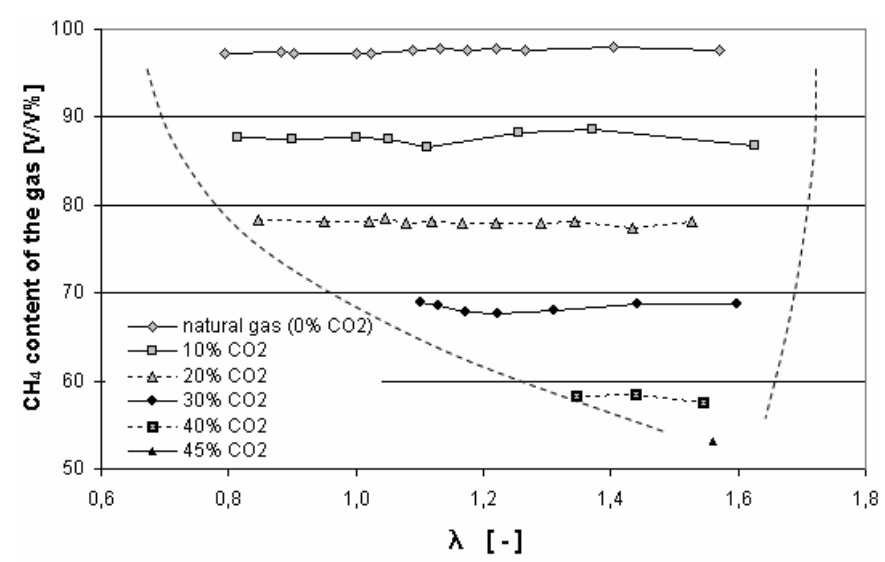

Fig. 2. Working range of the gas engine 


\subsection{Effect of biogas-fuelled running on the parameters of} engine

In all of the next figures it can be seen that the conventional gas engine cannot be operated stably with gaseous fuels with 45 $\%$ carbon-dioxide content. Therefore, the carbon-dioxide content of gas mixture needs to be limited to $40 \%$ or rather under this rate. It follows that in the biogas plant the objective can be to work out such biogas production recipe that can yield $\sim 70 \%$ methane biogas.

Fig. 3 shows the effective performance diagrams. The engine which operates the gas mixtures with 10-20\% carbon-dioxide content in the range of $\lambda=0.8-1.1$ air access coefficient is able to transmit almost the same values of the effective performance as in the case of operation with natural gas. The engine which operates the gas mixtures with $30 \%$ carbon-dioxide content in the range of $\lambda=1.1-1.2$ air access coefficient - the gaseous consumption increased, though - is able to produce values of the effective performance similar to natural gas operation. In the range of $\lambda>1.2$ air access coefficient the values of the effective performance to a small degree fall behind the values of the natural gas on the influence of the increasing carbon-dioxide.

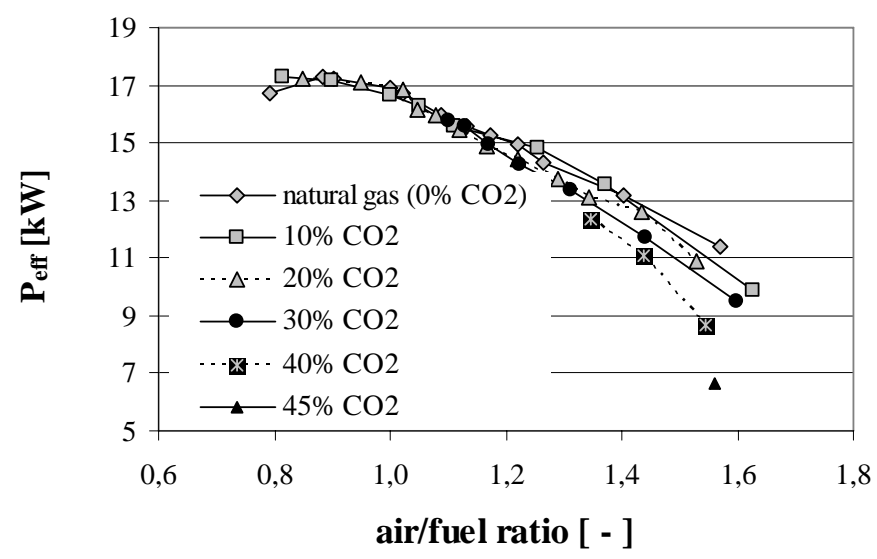

Fig. 3. Effective performance

In Fig. 4 it can be observed that in case of $\lambda>1.2$ air access coefficients the effective efficiency curves of the engine which operates the gas mixtures with over $30 \%$ carbon-dioxide content indicate decreasing of few percents.

\subsection{Effect of biogas-fuelled operation on the emission of engines}

Nitrogen $\left(\mathrm{N}_{2}\right)$ and nitrogen compounds $\left(\mathrm{NO}_{x}\right)$, oxygen $\left(\mathrm{O}_{2}\right)$, carbon-dioxide $\left(\mathrm{CO}_{2}\right)$, water vapour $\left(\mathrm{H}_{2} \mathrm{O}\right)$, carbon hydrogen $\left(\mathrm{C}_{n} \mathrm{H}_{m}\right)$, carbon monoxide $(\mathrm{CO})$ or particles can be found in the exhaust gas of the engine, in concentration depending on the operation state [5]. Basic requirements of the safe, economical and environment friendly energy supply are as deeply known as possible the main components of the exhaust gas, the exploring of quantitative and qualitative characteristics of the components. From the point of view of emission the air excess is the most important factor. The air access factor and the emission val-

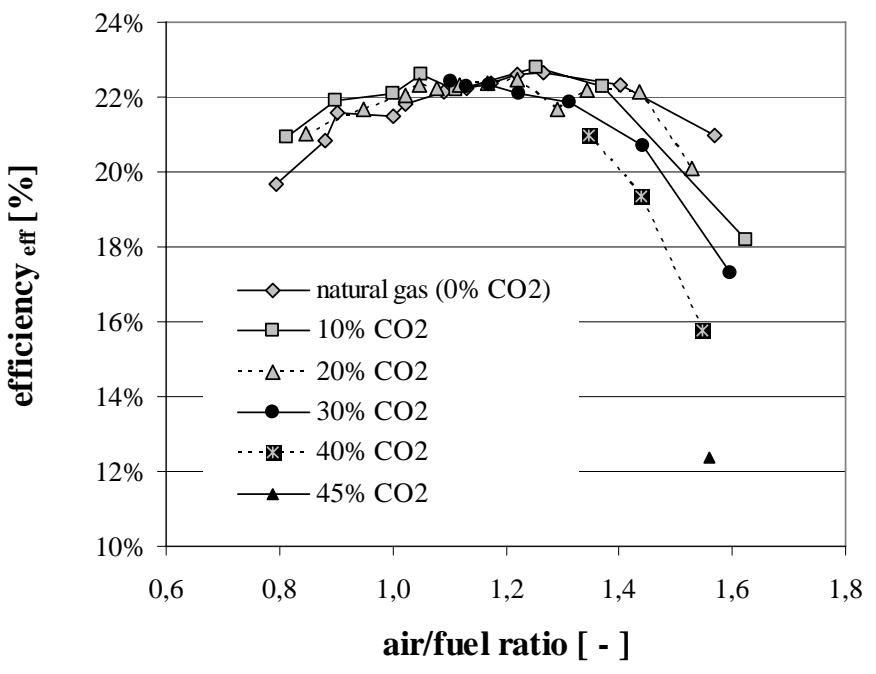

Fig. 4. Effective efficiency

ues supply information on the goodness of formation of air-fuel mixture. Further parameters apart from the air excess (ignition time, formation of combustion area, density ratio etc) influence the values of other emissions [4].

Fig. 5 shows the $\mathrm{CO}_{2}$ emission diagrams. However, the methane content of the biogas decreases while the carbondioxide content increases at the same time. This means that there is need for necessary surplus feeding from biogas with lower methane content towards just the same quantity of methane (gas with high energy content). The quantity of carbondioxide getting into engine with the fuel increases, which appears in the exhaust gas, too.

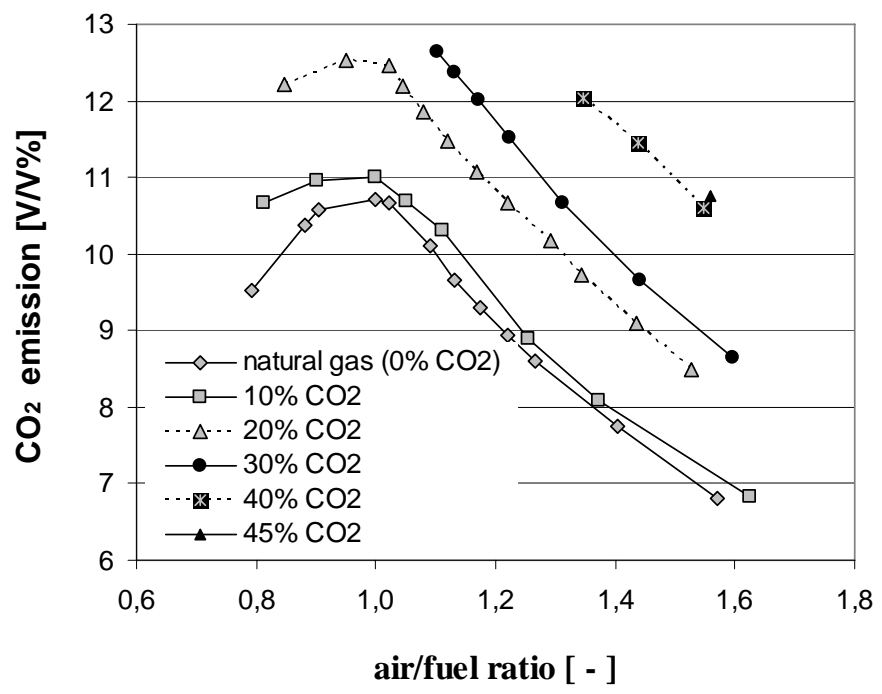

Fig. 5. $\mathrm{CO}_{2}$ emission

In Fig. 6 it can be seen that in case of $\lambda>1.1$ air access coefficients the cooling effect of the surplus air results lower $\mathrm{NO}_{x}$ emission, however, $\mathrm{NO}_{x}$ formation depends on the temperature. The engine operation with increasing carbon-dioxide content of gas mixture - by reason of drawing-off of combustion and cooling effect of carbon-dioxide - results further decreasing. 


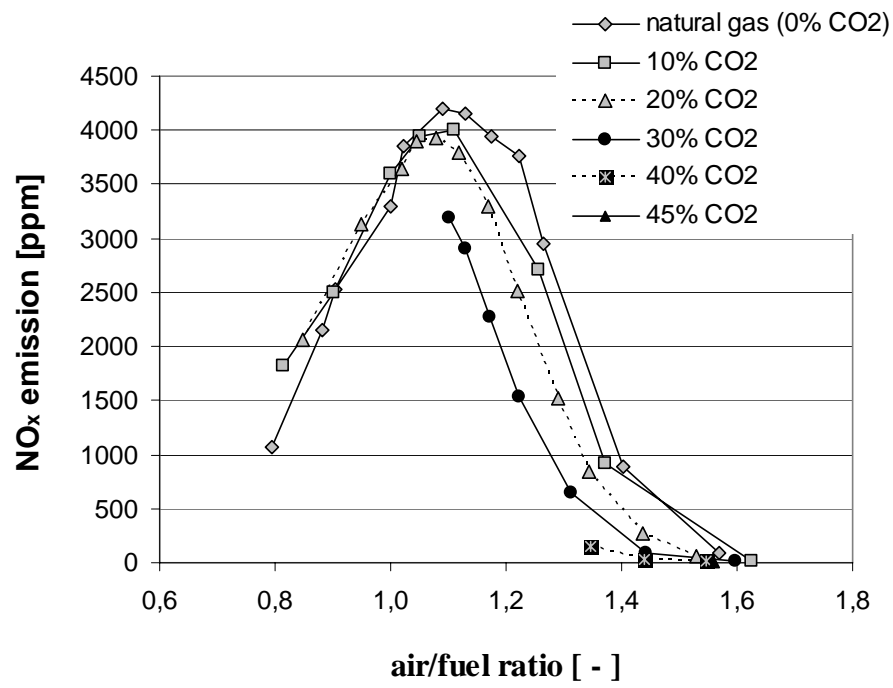

Fig. 6. $\mathrm{NO}_{x}$ emission

With increasing of carbon-dioxide rate of the applied energycarrier, the circumstances of the combustion are getting worse which result increasing $\mathrm{CO}$ emission and higher quantity of unburnt hydro-carbons. Fig. 7 illustrates the $\mathrm{CO}$ emission plotted against the air access coefficient.

In case of $\lambda<1.0$ air access coefficients $\mathrm{CO}$ emission increases by leaps and bounds, which can be explained by the increase of adiabatic flame temperature and production of getting rich mixture. However, in range of $\lambda=1.1-1.4$ air access coefficients CO emissions - independently of carbon-dioxide content of gas mixture-stabilized on lower values. In the case of $\lambda>1.4$ air access factors the dragging-on of combustion results increasing $\mathrm{CO}$ emission. In terms of $\mathrm{CO}$ emission, unambiguously, it can be determined that the traditional gas engine is operated with gas mixture with low methane content, there is no effect on $\mathrm{CO}$ emission if the gas engine operates permanently in range of $\lambda=1.1-14$ air access factors.

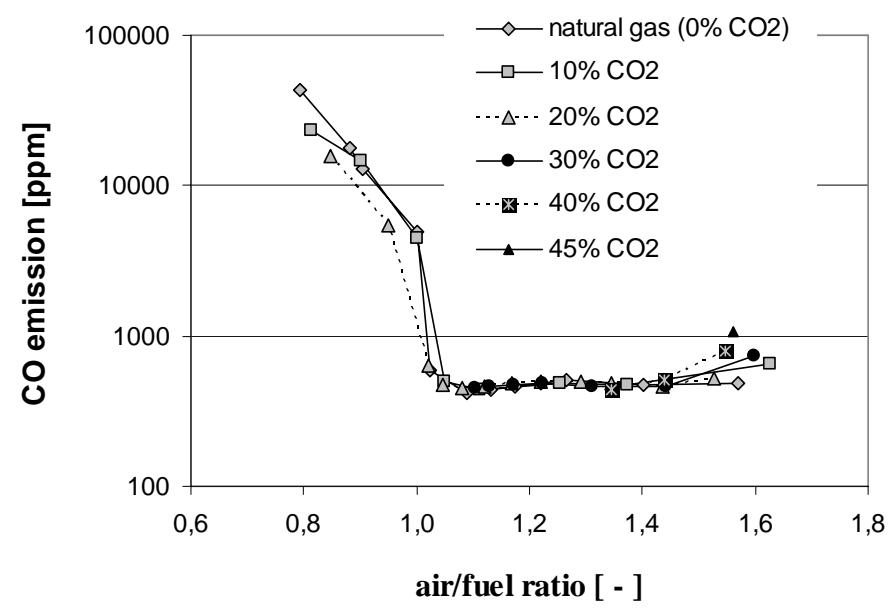

Fig. 7. $\mathrm{CO}$ emission

Measuring of the methane content in the exhaust gas can give points of reference on the goodness of combustion process. Increasing the air absence and dragging-on of the combustion re- sult similar tendencies considering the unburned hydrocarbons emission, too. In Fig. 8 it can be discovered that considering the incombustible hydrocarbon content of the exhausted gases there is no significant deviation present between the operation of natural gas and gas mixtures with a higher carbon-monoxide content in the range of $\lambda=1.2-1.4$ air access coefficient. The operation with low methane content of gas mixtures does not influence $\mathrm{CO}$ emission in the range of $\lambda=1.1-1.4$ air access coefficient.

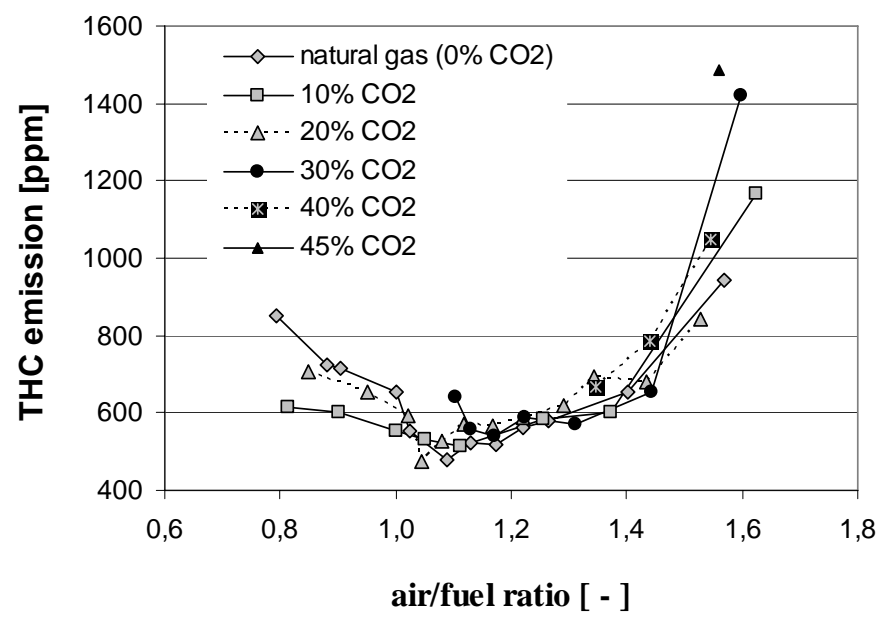

Fig. 8. THC emission

In our gas engine experiments we did not change the engine parameters. Practically, our measuring results cover the whole possible range, but we did not study further the changing of burning time. Our results relating to the emission of harmful materials show similarity to Crookes' results [1], who examines the emission of the combustion of some gas mixtures besides different compression relationships as well as analyses, researches of the relationship between the emission and the efficiency. Porpatham-Ramesh-Nagalingam [6, 7] the triple researcher made gas engine experiments by added compression ratio, at constant revolutions per minute at $25 \%$ throttle opening and at full throttle opening. On the grounds of their tests referring to the emission of gas engine they published partly different results from Crookes' and our results - which are difficult to support in theory.

\section{Statements, conclusions}

The preservation of the state of our environment and the effective, economical expectations of the energy needs can be solved with the harmonized application of the traditional and renewable energy sources. That is why in our days the best perspectives are hidden in the energetic utilization of biogas as a universal renewable source of energy, which is among the mostly pressed tasks. Carbon-dioxide content ( $\sim 25-60 \%$ ) of the biogas can be variable, depending on the organic material and the production technology. The combustion takes longer time on the effect of the carbon-dioxide, which brings forth changes in performance, efficiency and emission. 
On the grounds of the experimental results it can be determined that with the increasing of carbon-dioxide:

- the working range of the engine narrows

- the effective performance and the effective efficiency decrease significantly in case of higher air access

- gases with $40 \%$ carbon-dioxide content are safely just combustible in specially formed biogas engines

- it is practical to narrow the working range of the engine seeing that continuous operation in the range of $\lambda=1.2-1.6$ air access coefficients on the whole results lower emission.

\section{References}

1 Crookes R J, Comparative bio-fuel performance in internal combustion engines, Biomass and Bioenergy 30 (May 2006), 461-468, DOI 10.1016/j.biombioe.2005.11.022.

2 Kapros T, Biogáztüzelés az ipari berendezésekben., Biogáz-előállítás és felhasználás, Vol. I/1, pp. 38-41.

3 Kovács V B, Meggyes A, Investigation of Utilization of Low Heating Value Gaseous Fuels in Gas Engine, European Combustion Meeting ECM (Vienna, (Ausztria), 14, April 2009). CD issue.

4 Nagy V, Meggyes A, Utilization of biogas in gas engines, $8^{\text {th }}$ International Conference on Heat Engines and Environmental Protection, Balatonfüred, 28 May, 2007. Proceedings.

5 Paár I (ed.), Rendszeres Környezetvédelmi Felülvizsgálat, Közlekedéstudományi Intézet KHT, Budapest, 2005.

6 Porpatham E, Ramesh A, Nagalingam B, Investigations on the use of biogas and LPG in a spark ignition engine, PRITHVI International conference on environment friendly transportation (Trivandrum, India, February, 2005).

7 , Investigation on the effect of concentration of methane in biogas when used as a fuel for a spark ignition engine, Fuel 87 (2008), 1651-1659, DOI 10.1016/j.fuel.2007.08.014. 